\title{
Hubungan Jumlah Koloni Escherichia Coli dengan Derajat Dehidrasi pada Diare Akut
}

Felicia Halim, Sarah M. Warouw, Novie H. Rampengan, Praevilia Salendu

Bagian Ilmu Kesehatan Anak Fakultas Kedokteran Universitas Sam Ratulangi/Rumah Sakit Prof. dr. R. D. Kandou, Manado

Latar belakang. Escherichia coli (E. coli) penyebab kedua terbanyak diare setelah rotavirus. Diare E. coli sering disertai dengan dehidrasi yang berhubungan dengan morbiditas dan mortalitas anak.

Tujuan. Mengetahui peran jumlah koloni $E$. coli terhadap beratnya derajat dehidrasi diare akut.

Metode. Penelitian potong lintang dilakukan di RSUP Manado. Subyek umur 7 bulan-13 tahun dengan diare akut, dinilai derajat dehidrasi, dilakukan kultur tinja dan hitung jumlah koloni. Perbandingan jumlah koloni dan derajat dehidrasi dilakukan uji korelasi Gamma $(\mathrm{p}<0,05)$.

Hasil. Terdapat 50\% Escherichia coli dari 50 anak diare akut. Dehidrasi berat (2/25 anak), dehidrasi ringan sedang (13/25 anak) jumlah koloni $>10^{5} \mathrm{CFU}$ dan tanpa dehidrasi (10/25 anak) jumlah koloni $<10^{5} \mathrm{CFU}$. Analisis korelasi Gamma menyatakan hubungan bermakna jumlah koloni dengan derajat dehidrasi $\left(r_{G}=0,870\right.$, nilai $\left.\mathrm{p}=0,008\right)$.

Kesimpulan. Jumlah koloni Escherichia coli berperan terhadap derajat dehidrasi diare akut. Sari Pediatri 2017;19(2):81-5

Kata kunci: diare akut, koloni Escherichia coli, derajat dehidrasi

\section{Correlation between the Colonies Count of Escherichia Coli with The Grade of Dehydration in Acute Diarrhea}

Felicia Halim, Sarah M. Warouw, Novie H. Rampengan, Praevilia Salendu

Background. Escherichia coli is the second most common cause of diarrhea after rotavirus. Escherichia coli diarrhea is often accompanied by dehydration associated with morbidity and mortality of children.

Objective. Knowing the role of the number of colonies of Escherichia coli with the grade of dehydration from acute diarrhea.

Methods. A cross-sectional study was conducted in the hospital in Manado. Subjects aged 7 months-13 years with acute diarrhea were assessed the grade of dehydration, stool cultures taken and count the number of colonies. The number of colonies and the grade of dehydration was compared with Gamma correlation test $(\mathrm{p}<0.05)$.

Results. There were $50 \%$ Escherichia coli in 50 children with acute diarrhea. Severe dehydration (2/25 children), mild to moderate dehydration (13/25 children) with colonies count $>10^{5} \mathrm{CFU}$ and without dehydration $\left(10 / 25\right.$ children) with colonies count $<10^{5}$ CFU. Analysis Gamma correlation revealed that the number of colonies was related significantly with the grade of dehydration (rg $=0.870, \mathrm{p}=0.008)$.

Conclusions. The number of Escherichia coli colonies contribute to the grade of dehydration from acute diarrhea. Sari Pediatri 2017;19(2):81-5

Keywords: acute diarrhea, colonies of Escherichia coli, the grade of dehydration

Alamat korespondensi: Dr. Felicia Halim. Bagian Ilmu Kesehatan Anak Fakultas Kedokteran Universitas Sam Ratulangi, Rumah Sakit Prof. dr. R. D. kandou Jl. Raya Tanawangko, Manado. Email : halimfeliciamd@gmail.com 
$\mathrm{P}$ enyakit diare merupakan penyebab utama morbiditas dan mortalitas pada anak di negara berkembang. Terdapat 6 juta anak meninggal per tahun di dunia karena diare, sebagian besar terdapat di negara berkembang. Menurut World Health Organization (WHO), penyakit diare merupakan salah satu penyebab utama kematian Balita di negara berkembang. Angka kejadian diare pada anak tiap tahun diperkirakan 2,5 milyar. Secara global, 1,6 juta Balita meninggal setiap tahun akibat penyakit ini. ${ }^{1}$

Data dari Kementerian kesehatan Republik Indonesia melaporkan 100.000 Balita meninggal per tahun karena diare, setiap hari ada 273 Balita meninggal, sebanding dengan 11 jiwa meninggal setiap jam atau 1 jiwa setiap 5,5 menit akibat diare. ${ }^{2-3}$

Penyebab diare terbanyak setelah rotavirus adalah Escherichia coli. Bakteri ini merupakan bakteri komensal, patogen intestinal dan patogen ekstra intestinal yang dapat menyebabkan infeksi saluran kemih, meningitis dan septicemia. Sebagian besar dari E. coli berada dalam saluran pencernaan, tetapi yang bersifat patogen menyebabkan diare pada manusia. ${ }^{4,5}$

Diare yang disebabkan oleh Escherichia coli merupakan patogen enterik yang dapat menyebabkan dehidrasi dengan berbagai mekanisme tergantung jenis patotipenya. Jumlah koloninya dalam usus dapat memengaruhi beratnya gejala diare. Standar emas untuk mendiagnosis dehidrasi adalah dengan mengukur kehilangan berat badan akut. Namun, berat badan sebelum sakit pada umumnya tidak diketahui, maka perkiraan kehilangan cairan dilakukan berdasarkan penilaian klinis. Semakin berat derajat dehidrasi mengakibatkan peningkatan morbiditas dan mortalitas. ${ }^{6,7}$

Penelitian ini bertujuan untuk mengetahui peranan jumlah koloni Escherichia coli terhadap derajat dehidrasi anak dengan diare akut.

\section{Metode}

Penelitian analitik observasional dengan rancangan potong lintang. Pemilihan subyek dilakukan secara berurutan sampai memenuhi jumlah sampel yang telah dihitung yaitu 16 subyek dengan nilai $\alpha .1,64$ dan $\beta$ 0,84. Subyek penelitian adalah anak dengan diare akut yang dirawat di RSUP. Manado. Kriteria inklusi yaitu berumur 7 bulan sampai 13 tahun dan orang tua menyetujui ikut serta dalam penelitian. Kriteria eksklusi, yaitu telah mendapat antibiotik 7 hari terakhir, telah mendapat probiotik 7 hari terakhir, gizi buruk dan hanya mengkonsumsi ASI saja. Variabel bebas adalah jumlah koloni Escherichia coli. Variabel tergantung adalah derajat dehidrasi.

Subyek yang memenuhi kriteria inklusi, sebelumnya dimintai persetujuan dari orang tua, kemudian dilakukan anamnesis, pemeriksaan fisik, dinilai status dehidrasinya, status antropometri dan dilakukan pemeriksaan feses lengkap, kultur tinja serta hitung jumlah koloni.

Karakteristik umum subyek dideskriptifkan, sedangkan untuk analisis perbandingan antar variabel digunakan uji korelasi Gamma. Data yang terkumpul ditabulasi dan diolah secara statistik menggunakan program SPSS 22 dengan nilai $\mathrm{p}<0,05$.

Penelitian ini telah mendapat persetujuan Komite Etik Penelitian kesehatan rumah sakit.

\section{Hasil}

Terdapat 50 subyek dengan diare akut yang ikut serta dalam penelitian ini. Kuman penyebabnya adalah Escherichia coli sebanyak 25 (50\%) diikuti dengan Coccus Gram negatif 6 sampel, Klebsiella sp 6 sampel, Staphylococcus hemoliticus 1 sampel, Yersinia pseudotuberculosis 1 sampel, Providencia rettger 1 sampel, Proteus stuartii 1 sampel, Streptococcus sp 1 sampel dan Pseudomonas sp 1 sampel, sedangkan 7 sampel tidak ada pertumbuhan kuman.

Tabel 1 menunjukkan karakteristik umum subyek penelitian berdasarkan jenis kelamin, usia, frekuensi diare, gejala penyerta dan derajat dehidrasi.

Tabel 2 menunjukkan perbandingan antara jumlah koloni dengan derajat dehidrasi yang menunjukkan hubungan yang sangat kuat dan bermakna antara jumlah koloni Escherichia coli dengan derajat dehidrasi pada diare akut.

\section{Pembahasan}

Penyakit diare merupakan penyebab utama morbiditas dan morbiditas pada anak. Badan Kesehatan Dunia (WHO) memperkirakan bahwa 6 juta anak meninggal tiap tahun oleh karena diare akut. Bakteri yang paling 
Felicia Halim dkk: Hubungan jumlah koloni E. Coli dengan derajat dehidrasi pada diare akut

Tabel 1. Karakteristik umum subyek penelitian

\begin{tabular}{lc}
\hline Karakteristik & $\mathrm{n}$ \\
\hline Jenis kelamin & 16 \\
Laki-laki & 9 \\
$\quad$ Perempuan & 2,7128 (SD 2,70513) \\
Usia & 6,52 (SD 3,525) \\
Frekuensi & \\
Gejala penyerta & 1 \\
Demam & 1 \\
Demam, batuk & 1 \\
Demam, batuk, sesak, kejang & 2 \\
Demam, kejang & 13 \\
Demam, muntah & 2 \\
Demam, muntah, kejang & 2 \\
Demam, muntah, nyeri perut & 1 \\
Demam, penurunan kesadaran & 2 \\
Muntah & \\
Derajat dehidrasi & 2 \\
Dehidrasi berat & 13 \\
Dehidrasi ringan sedang & 10 \\
Tanpa dehidrasi & \\
\hline
\end{tabular}

Tabel 2. Perbandingan jumlah koloni E. coli dengan derajat dehidrasi

\begin{tabular}{lcccc}
\hline Derajat dehidrasi & \multicolumn{2}{c}{ Koloni } & Total & Korelasi \\
\cline { 2 - 4 } & $<10^{5}(\%)$ & $\begin{array}{c}>10^{5} \\
(\%)\end{array}$ & & \\
\hline Tanpa dehidrasi & 5 & 5 & 10 & $\mathrm{r}_{\mathrm{G}}=0,870$ \\
\hline Ringan sedang & 1 & 12 & 13 & $\mathrm{p}=0,008$ \\
Berat & 0 & 2 & 2 & \\
\hline
\end{tabular}

sering menyebabkan diare adalah E. coli. ${ }^{5,8}$ Terdapat 6 patotipe DEC yang dapat menyebabkan penyakit gastroenteritis, yaitu Enteropathogenic Escherichia coli (EPEC), Enterotoxigenic escherichia coli (ETEC), Shiga Toxin-producing E. coli (STEC), Enteroaggregative E. coli (EAEC), Difusse-adhering E. coli (DAEC) dan Enteroinvasive E. coli (EIEC). ${ }^{9-11}$

Di negara berkembang 50\%-60\% kasus diare disebabkan oleh bakteri (EPEC 25\%, Campylobacter jejuni 10\%-18\%, Shigella sp (5\%) dan Salmonella $s p(5 \%)$ dan $(35 \%)$ oleh virus. ${ }^{12}$ Beberapa studi mendapatkan bahwa $E$. coli merupakan satu-satunya penyebab diare yang tersering pada bayi, anak presekolah dan anak sekolah. Pada studi yang dilakukan di Porto Velho (Brasil), diantara 470 anak berusia dibawah 72 bulan dengan diare didapatkan prevalensi E. coli $18,2 \% .{ }^{13}$ Sesuai dengan penelitian kami didapatkan 50\% kasus diare disebabkan oleh E. coli.
Hal ini disebabkan oleh kebersihan individu dan orang tua yang kurang.

Di antara anak usia sekolah juga didapatkan E. coli yang merupakan penyebab diare tersering. Di Dhaka, Bangladesh, sebuah studi dilakukan pada anak di atas umur 5 tahun didapatkan $74,8 \%$ penyebabnya adalah E. coli. Studi lainnya juga dilakukan pada negara yang sama dengan populasi yang berbeda didapatkan E. coli menyebabkan diare $(45,2 \%) .{ }^{14} \mathrm{Hal}$ tersebut sesuai dengan penelitian kami, populasi terbanyak adalah anak yang berumur di atas 5 tahun.

Faktor yang memengaruhi interpretasi kolonisasi patogen dari anak dengan diare meliputi faktor bakteri (bakteri dengan gen yang lebih virulen), faktor host (umur, paparan sebelumnya, imunitas dan faktor protektif dari ASI), faktor lingkungan (higiene yang kurang dan kontaminasi fekal). ${ }^{6,8}$ Namun, penelitian ini hanya membahas mengenai faktor dari bakteri saja. 
Dalam studi sebelumnya ditunjukkan bahwa anak di bawah 12 bulan dengan diare memiliki kolonisasi bakteri lebih tinggi dibandingkan dengan anak sehat. Pada anak yang menyusui, hasil kultur tinjanya tidak ada perbedaan yang bermakna dalam hal jumlah koloni bakteri antara diare dan kontrol. Namun, anak yang diare dan tidak menyusui didapatkan koloni bakteri yang lebih banyak. ${ }^{10}$

Penelitian lainnya melakukan kultur kuantitatif tinja dari kelinci dengan diare didapatkan bakteri yang lebih banyak dengan rerata 1,1 X $10^{8} \mathrm{CFU}$ per Gram tinja, nilai median $1.6 \times 10^{8} \mathrm{CFU}$ dibandingkan kelinci tanpa diare nilai rerata $2,8 \times 10^{4} \mathrm{CFU}$, nilai median $3.9 \times 10^{4} \mathrm{CFU}$ (nilai $\mathrm{p}<.0001$ ). ${ }^{15}$

Studi multisenter di Gambia, Mali, Kenya, dan Bangladesh dilakukan penelitian menggunakan PCR kuantitatif untuk mendeteksi gen ipaH Shigella di dalam sampel tinja pada 3533 anak berumur kurang dari 59 bulan dengan dehidrasi sedang berat atau tanpa diare. Individu yang terdeteksi $\geq 2,9 \times 10^{4} \mathrm{ipaH}$ memiliki risiko 5-6 kali terjadi diare dibandingkan dengan yang $<2,9 \times 10^{4}$ (IK 95\%, 3,7-8,5, p<0,0001). Pada kasus diare dehidrasi sedang berat didapat pada 155 kasus dan semuanya memiliki jumlah ipaH sangat banyak. Hal ini menyatakan bahwa makin banyak jumlah koloni kuman Shigella, semakin banyak jumlah gen ipaH menyebabkan semakin berat derajat dehidrasi daripada diare. ${ }^{16}$ Studi ini sesuai dengan hasil temuan kami mengenai jumlah koloni pada diare dengan dehidrasi ringan sedang dan berat lebih banyak daripada diare tanpa dehidrasi.

Di Meksiko, anak yang terkena diare oleh E. coli didapatkan gen virulensi tambahan berupa dispersin, aat $\mathrm{A}$, dispersin-translocator (aatA), enteroaggregative heat-stable toxin 1 (astA), plasmid encoded toxin (pet), cytolethal distending toxin (cdt) lebih banyak pada $E$. coli dibandingkan bakteri yang lain $(36 \%$ vs $26 \%$, $\mathrm{p}<0,0001$, OR 4,2, IK 95\%) sehingga disimpulkan $E$. coli yang membawa gen virulensi tersebut dapat menyebabkan diare dengan dehidrasi sedang sampai berat. ${ }^{17}$ Studi ini mendukung hasil penelitian kami yang mendapatkan jumlah koloni sedikit $\left(<10^{5}\right.$ CFU) menunjukkan gejala dehidrasi. Hal tersebut kemungkinan disebabkan oleh gen virulensi tambahan yang dibawa oleh patogen penyebab.

Kebanyakan episode diare oleh karena $E$. coli bersifat self-limiting, tetapi beberapa kasus yang berkembang menjadi dehidrasi dan meninggal. Oleh sebab itu, penting untuk mengetahui faktor risiko yang berhubungan dengan kejadian dehidrasi karena intervensi yang cepat dapat mencegah terjadinya dehidrasi dan kematian. Terapi rehidrasi oral telah tersedia sejak 30 tahun yang lalu dan penggunaannya telah menurunkan angka mortalitas karena diare, tetapi angka morbiditas masih menjadi masalah utama pada anak di bawah umur 5 tahun khususnya dibawah 1 tahun. ${ }^{18,19}$

Terdapat beberapa studi yang mengidentifikasi sosioekonomi, lingkungan, maternal, nutrisional dan karakteristik lain sebagai faktor risiko morbiditas dan mortalitas diare. Kemiskinan, pendidikan orangtua yang rendah, sanitasi jelek, kurang tersedianya air bersih, prematur, interval kelahiran yang pendek, kurangnya menyusui dan malnutrisi merupakan faktor yang berhubungan dengan diare. ${ }^{18,19}$

Keterbatasan penelitian ini tidak dilakukan pemeriksaan PCR untuk meneliti strain E. coli yang sering menyebabkan diare dan tidak meneliti faktor lain yang memengaruhi derajat dehidrasi pada anak dengan diare akut.

\section{Kesimpulan}

Pada diare akut yang disebabkan E. coli, semakin banyak jumlah koloni $E$. coli, berpeluang pada semakin berat derajat dehidrasinya.

\section{Daftar pustaka}

1. World Health Organization. The world health report 2003. Geneva :WHO; 2003.

2. Departemen kesehatan RI. Kepmenkes RI No. 1216/Menkes/ SK/XI/2001 Tentang pedoman pemberantasan penyakit diare. Jakarta : Ditjen PP \& PL, Departemen Kesehatan RI; 2007.

3. Departemen Kesehatan RI. Riset kesehatan dasar tahun 2007. Jakarta: Departemen Kesehatan RI; 2007.

4. Web A, Starr M. Acute gastroenteritis in children. Aust Fam Physician 2005;34:227-31.

5. Farthing M, Salam MA, Lindberg G, Dite P. Acute Diarrhea in Adults and Children: A global perspective. World Gastroenterology Organisation Global Guidelines. J Clin Gastroenterol 2013;47:12-20.

6. Ifeanyi CIC, Ikeneche NF, Bassey BE, Gallas N, Aissa RB, Boudabous A. Diarrhegenic Escherichia coli pathotypes isolated from children with diarrhea in the Federal Capital 
Territory Abuja Nigeria. J Infect Dev Ctries 2015;9:165-74.

7. Barletta F, Ochoa TJ, Mercado E, dkk. Quantitative real-time polymerase chain reaction for enteropathogenic Escherichia coli: a tool for investigation of asymptomatic versus symptomatic infections. CID 2011;53:1223-9.

8. Bryce J, Boschi-pinto C, Shibuya K, Black RE. WHO estimates of the causes of death in children. Lancet 2005;365:1147-52.

9. Podewils LJ, Mintz ED, Nataro JP, Parashar UD. Acute infectious diarrhea among children in developing countries. J Spid 2004;5:155-65.

10. Kaper JB, Nataro JP, Mobley HLT. Pathogenic Escherichia coli. Nat Rev Microbiol 2004;2:123-41.

11. Croxen MA, Finlay BB. Molecular mechanisms of Escherichia coli pathogenicity. Nat Rev 2010;8:26-38.

12. Cheng AC, McDonald JR, Thielman NM. Infectious diarrhea in developed and developing countries. J Clin Gastroenterol 2005;39:757-73.

13. Orlandi PP, Magalhaes GF, Matos NB, Silva T, Penatti M, Nogueira PA, dkk. Etiology of diarrheal infection in children of Porto Velho (Rondonia, Western Amazon region, Brazil). Brazilian J Med Bio Res 2006;39:507-17.

14. Haque R, Mondal D, Kirkpatrick BD, Akther S, Farr BM, Sack
RB, dkk. Epidemiologic and clinical characteristics of acute diarrhea with emphasis on entamoeba hystolitica infections in preschool children in an urban slum of Dhaka, Bangladesh. J Trop Med Hyg 2003;69:398-405.

15. Robin-Browne RM, Levine MM. Laboratory diagnostic challenges in case/control studies of diarrhea in developing countries. CID 2012;55:312-6.

16. Lindsay B, Ochieng JB, Ikumapayi UN, dkk. Quantitative PCR for detection of Shigella improves ascertainment of shigella burden in children with moderate to severe diarrhea in low income countries. J Clin Microbiol 2013;51:1740-6.

17. Patzi-Vargas S, Zaidi MB, Perez-Martinez I, dkk. Diarrhegenic Escherichia coli carrying supplementary virulence genes are an important cause of moderate to severe diarrhoeal disease in Mexico. Plos Negl Trop Dis 2015;9:1-18.

18. Fuchs SC, Victora CG. Risk and prognostic factors for diarrheal disease in Brazilian infants: a special case-control design application. Cad Saude Publica 2002;18:773-82.

19. Zodpey SP, Deshpande SG, Ughade SN, Hinge AV, Shrikhande SN. Risk factors for development of dehydration in children aged under five who have acute watery diarrhea: a case-control study. Pub Health 1998;112:233-6. 